\title{
Combination of Coagulation, Adsorption, and Ultrafiltration Processes for Organic Matter Removal from Peat Water
}

\author{
Muthia Elma ${ }^{1,2, *(1)}$, Amalia Enggar Pratiwi ${ }^{1,2}$, Aulia Rahma ${ }^{2}$, Erdina Lulu Atika Rampun ${ }^{2}$, Mahmud Mahmud ${ }^{3, *}$, \\ Chairul Abdi ${ }^{3}$, Raissa Rosadi ${ }^{2,4}$, Dede Heri Yuli Yanto ${ }^{5}$ (D) and Muhammad Roil Bilad ${ }^{6}$ (i)
}

1 Department of Chemical Engineering, Faculty of Engineering, Lambung Mangkurat University, Jl. A. Yani KM 36, Banjarbaru 70714, Indonesia; aepratiwi@ulm.ac.id

2 Materials and Membranes Research Group ( $\left.\mathrm{M}^{2} \mathrm{ReG}\right)$, Lambung Mangkurat University, Jl. A. Yani KM 36, Banjarbaru 70714, Indonesia; arahma@mhs.ulm.ac.id (A.R.); erdinalulu@gmail.com (E.L.A.R.); raissa.rosadi@gmail.com (R.R.)

3 Department of Environment Engineering, Faculty of Engineering, Lambung Mangkurat University, Jl. A. Yani KM 36, Banjarbaru 70714, Indonesia; cabdi@ulm.ac.id

4 Postgraduate Program, Department of Natural Resource and Environmental Management, Lambung Mangkurat University, Jl. A. Yani KM 36, Banjarbaru 70714, Indonesia

5 Research Center for Biomaterials, National Research and Innovation Agency (BRIN), Cibinong Science Center, Cibinong, Jl. Raya Bogor KM 46, Bogor 16911, Indonesia; dede.heri.yuli.yanto@brin.go.id

6 Faculty of Integrated Technologies, Universiti Brunei Darussalam, Gadong BE1410, Brunei; roil.bilad@ubd.edu.bn

* Correspondence: melma@ulm.ac.id (M.E.); mahmud@ulm.ac.id (M.M.)

Citation: Elma, M.; Pratiwi, A.E.;

Rahma, A.; Rampun, E.L.A.;

Mahmud, M.; Abdi, C.; Rosadi, R.;

Yanto, D.H.Y.; Bilad, M.R.

Combination of Coagulation,

Adsorption, and Ultrafiltration

Processes for Organic Matter

Removal from Peat Water.

Sustainability 2022, 14, 370. https://

doi.org/10.3390/su14010370

Academic Editors: Mohd Rafatullah and Masoom Raza Siddiqui

Received: 3 December 2021

Accepted: 27 December 2021

Published: 30 December 2021

Publisher's Note: MDPI stays neutral with regard to jurisdictional claims in published maps and institutional affiliations.

Copyright: (c) 2021 by the authors Licensee MDPI, Basel, Switzerland. This article is an open access article distributed under the terms and conditions of the Creative Commons Attribution (CC BY) license (https:// creativecommons.org/licenses/by/ $4.0 /)$.

\begin{abstract}
The high content of natural organic matter (NOM) is one of the challenging characteristics of peat water. It is also highly contaminated and contributes to some water-borne diseases. Before being used for potable purposes, peat water must undergo a series of treatments, particularly for NOM removal. This study investigated the effect of coagulation using aluminum sulfate coagulant and adsorption using powdered activated carbon (PAC) as a pretreatment of ultrafiltration (UF) for removal of NOM from actual peat water. After preparation and characterization of polysulfone (Psf)-based membrane, the system's performance was evaluated using actual peat water, particularly on NOM removal and the UF performances. The coagulation and adsorption tests were done under variable dosings. Results show that pretreatment through coagulation-adsorption successfully removed most of the NOM. As such, the UF fouling propensity of the pretreated peat water was substantially lowered. The optimum aluminum sulfate dosing of $175 \mathrm{mg} / \mathrm{L}$ as the first pretreatment stage removed up to 75-78\% NOM. Further treatment using the PAC-based adsorption process further increased 92-96\% NOM removals at an optimum PAC dosing of $120 \mathrm{mg} / \mathrm{L}$. The final UF-PSf treatment reached NOM removals of $95 \%$ with high filtration fluxes of up to $92.4 \mathrm{~L} /\left(\mathrm{m}^{2} . \mathrm{h}\right)$. The combination of three treatment stages showed enhanced UF performance thanks to partial pre-removal of NOM that otherwise might cause severe membrane fouling.
\end{abstract}

Keywords: coagulation-adsorption; membrane; organic matter; peat water; ultrafiltration; polysulfone

\section{Introduction}

The supply of high-quality freshwater is a crucial problem in rural areas. In many cases, water resources are of inferior quality (i.e., peat water), making it inconsumable without implementing advanced treatments. Peat water is one of the water sources that are still untapped. It is characteristically acidic ( $\mathrm{pH}$ 5.9) and high in natural organic matter (NOM), identified using three standard parameters of the non-specific indicator: dissolved organic carbon (DOC, $36.40 \mathrm{mg} / \mathrm{L})$, UV absorbance $254 \mathrm{~nm}(0.955$ 1/cm), and organic substances $\left(113.76 \mathrm{mg} \mathrm{KMnO}_{4} / \mathrm{L}\right)$. NOM in peat water may exert odors, aromatization, biological instability, and corrosion of water distribution networks [1]. Conventional water treatments for removal NOM have been widely applied by standalone processes such 
as coagulation-flocculation and sedimentation [2], activated carbon adsorption [3], and filtration [4]. However, they do not provide optimal treatment for removing NOM.

Previous studies have reported types of water and wastewater treatments that contain high NOM using standalone coagulation, with about $60-70 \%$ removal of hydrophobic fraction of NOM and $30-40 \%$ of hydrophilic fractions [5-8]. Another work also reported performance of adsorption for NOM removals of up to $98 \%$ that were obtained by powdered activated carbon (PAC) with an optimum dosage $500 \mathrm{mg} / \mathrm{L}$ [9], which can remove organic materials with a molecular weight (MW) ranging from $0.5-1$ to $1-3 \mathrm{kDa}$. Nevertheless, it could not remove NOM with an MW of $<0.5 \mathrm{kDa}[10,11]$. In addition, the adsorbent may be saturated due to the complete occupation of the adsorption site, while reactivation of the adsorbent results in a complex operation, which may lead performance to decrease [12].

Membrane technology is an advanced treatment process for treating NOM in water, such as wetland or peat water [13-17]. Several studies were reported successful treatment of wetland saline water by pervaporation using silica-based membranes [18-21], wetland saline water by pure silica membrane and organosilica-based membranes [22-28]. Another study showed ultrafiltration (UF) membrane for removal fraction of NOM from peat water [29]. The UF technology is more applicable and better for reducing NOM in water compared with pervaporation. The pervaporation setup is more complex than UF. However, despite NOM's effective removal by the membrane, it is also able to decline membrane performance through membrane fouling [30,31]. Fouling is a major factor that may decrease membrane flux during the separation process, especially the ultrafiltration.

Membrane fouling in peat water treatment is mainly caused by NOM through both the hydrophilic and the hydrophobic fractions [32]. The most common methods to reduce membrane fouling are by altering the physical and chemical properties of the membrane materials by adding additives in the fabrication stage [33-36] or by applying pretreatment of the feed in the operational stages [32,37]. In this study, both coagulation and adsorption were investigated for the first time as a pretreatment of UF for the treatment of real peat water.

This paper reports a preliminary study on NOM removal from peat water by using both aluminum sulfate-based coagulation and PAC-based adsorption as a pretreatment of UF. The polysulfone (PSf) UF membrane was first prepared and characterized. Before being used for the pretreated peat water filtration. The NOM composition in the peat water samples was then characterized. Finally, actual peat water was treated using a series of treatments, namely aluminum sulfate-based coagulation, PAC-based adsorption, and filtration using the developed Psf-UF membrane.

\section{Materials and Methods}

\subsection{Peat Water Characterization}

The peat water sample was taken from Banjar Regency, South Kalimantan, Indonesia. Preliminary characterization of peat water included measuring $\mathrm{pH}$ using a $\mathrm{pH}$ meter (Hanna Hi2211), $\mathrm{KMnO}_{4}$ - oxidizable organic substances using the permanganate titrimetric method, and aromatic organic matter absorbance of $\mathrm{UV}_{254}$, and DOC by a total organic carbon analyzer (Shimadzu TOC-L). The permanganate titration method was conducted according to Standard (SNI 06-6989.22-2004). The $\mathrm{UV}_{254}$ parameter was measured by a UV visible (UV-1600 Spectrophotometer). On the other hand, DOC was analyzed by high-temperature catalytic oxidation with non-dispersive infrared (NIDR) detection. As a pretreatment, the samples were filtered using Whatman $0.45 \mu \mathrm{m}$ before being tested by TOC analyzer. Meanwhile, specific UV absorbance (SUVA $254, \mathrm{~L} / \mathrm{mg} \cdot \mathrm{m}$ ) was used to represent TOC normalized aromatic moieties $\left(\mathrm{UV}_{254}\right)$. Meanwhile, specific $U V$ absorbance $\left(\mathrm{SUVA}_{254}, \mathrm{~L} / \mathrm{mg} \cdot \mathrm{m}\right)$ was used to represent TOC normalized aromatic moieties $\left(\mathrm{UV}_{254}\right)$ by dividing of the $\mathrm{UV}_{254}$ with the DOC value. 


\subsection{Membrane Preparation and Characterization}

The dope solution for Psf UF membrane preparation was made using $18 \mathrm{wt}$ \% of Psf (Merck) as the polymer, $64 \mathrm{wt}$ \% dimethylacetamide (DMAc, Merck) as the solvent, and polyethylene glycol (PEG, Merck) PEG 600 as the additive (18 wt.\%). According to earlier reports, the membranes were prepared using the phase inversion method [35]. The polymer, solvent, and additive were mixed and stirred until homogeneous. Then, the solution was left idle overnight to release the entrapped bubbles. Subsequently, the dope solution was cast on a glass plate at a wet casting thickness of $165 \mu \mathrm{m}$ using a casting applicator. The phase inversion was then continued by immersing the cast film into a coagulation bath containing nonsolvent solution comprising of DMAc $35 \mathrm{wt} . \%$ and $\mathrm{KCl} 0.5 \mathrm{wt} . \%$ in water.

The hydraulic resistance of the prepared membrane was characterized by measuring the clean water permeability, and a scanning electron microscopy (SEM) was used to determine the membrane PSf morphology and membrane thickness. The pore size of the membranes was determined using image-J software from the surface of the SEM image [38]. The permeability test was conducted by flowing the distilled water on a dead-end system filtration device. The permeate volume was then measured every 5 min intervals for $60 \mathrm{~min}$ operation time under different pressures of 1, 1.5, 2, 2.5, and 3 bar.

\subsection{Coagulation, Adsorption, and Ultrafiltration}

The coagulation tests were done by varying doses of aluminum sulfate (one of the most common coagulants) in a range of $125-250 \mathrm{mg} / \mathrm{L}$ using the Jar-test method at adjusting $\mathrm{pH}$ 6 (regulated by drop-wise adding $0.1 \mathrm{M} \mathrm{NaOH}$ (Merck)) with a working volume of $1.2 \mathrm{~L}$. During the jar test, the coagulant mixture in peat water was stirred at $100 \mathrm{rpm}$ for $1 \mathrm{~min}$, followed by slow stirring at $40 \mathrm{rpm}$ for $20 \mathrm{~min}$ and sedimentation for $20 \mathrm{~min}$, according to a protocol reported earlier [39]. The range of the coagulant dosage was defined based on a previous study [31].

The PAC adsorption tests were done using the Jar-test under varying $20-200 \mathrm{mg} / \mathrm{L}$ doses. It was carried out for the pretreated peat water through coagulation/flocculation. The feed and PAC (particle size of 100 mesh; surface area of $800 \mathrm{~m}^{2} / \mathrm{g}$, Merck) were mixed with a rotary shaker at $180 \mathrm{rpm}$ for $3 \mathrm{~h}$.

After coagulation and adsorption, the treated supernatant underwent a UF-200 mL of the supernatant was filtered using the developed UF PSf membrane by using a standard dead-end filtration cell (Figure 1) according to a protocol detailed elsewhere [30]. The filtrations were done at variable pressures of 1, 1.5, 2, 2.5, 3 bar for 60 min at room temperature of feed $\left(25^{\circ} \mathrm{C}\right)$, stirred at $50 \mathrm{rpm}$. A gas compressor generated the pressure, and the permeate volume was collected every $5 \mathrm{~min}$. All of the coagulatin, adsorption, and filtration experiments were done in triplicate.

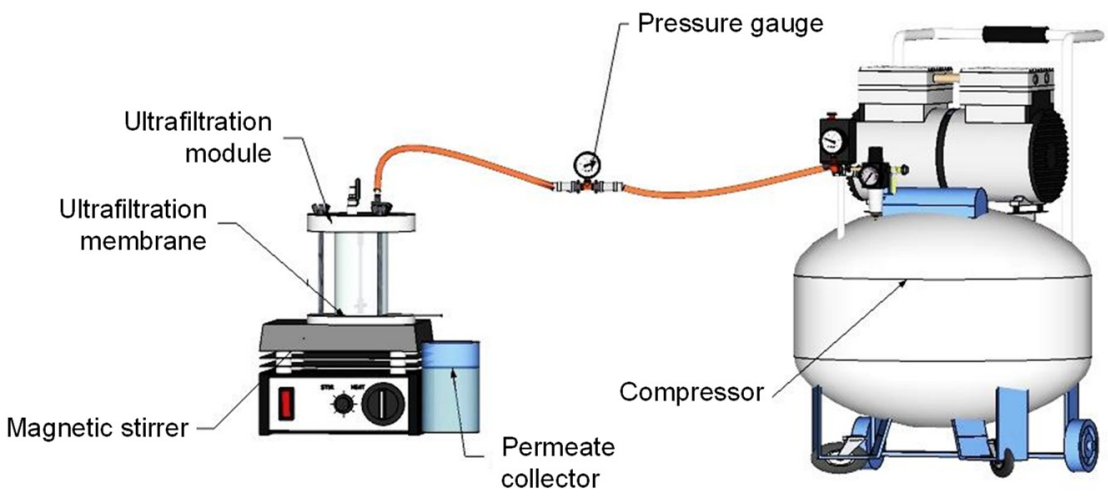

Figure 1. Illustration of the ultrafiltration dead-end experimental setup. 


\section{Results}

\subsection{Peat Water Characteristics}

The characterizations of peat water were carried out for four periods to monitor the changes of NOM content of the peat water samples, as summarized in Table 1. It shows that the peat water had a neutral $\mathrm{pH}$, similar to previous reports where the $\mathrm{pH}$ value on surface water ranged from 5.0-8.1 [31]. The high NOM content was indicated by the DOC values $[39,40]$, the absorbance value of $\mathrm{UV}_{254}$, which are high compared with the results obtained by Kang and Choo [41] and Jeong et al. [42] of $\mathrm{UV}_{254}<0.1 \mathrm{~cm}^{-1}$ for surface water. However, compared with the results obtained elsewhere Herwati, Mahmud, and Abdi [30], Mahmud, Abdi, and Mu'min [31], Saputra [37], Aisyahwalsiah [39] showed the $U_{254}$ absorbance of the peat water samples was relatively low. Similar to the $U_{2} V_{254}$ absorbance value, the $\mathrm{SUVA}_{254}$ values of the peat water sample deviated from others (Zularisam et al. [43]). Based on their reports, the SUVA 254 characteristic of peat water contained a high hydrophobic fraction. The $\mathrm{SUVA}_{254}$ values of the peat water sample in this study ranged at 2-3 L/mg.m suggesting the mixture of hydrophobic and hydrophilic substances NOM characteristics, with a large range of MWs. Similar results were found in previous research on surface water that reported $\mathrm{SUVA}_{254}$ of $<2 \mathrm{~L} / \mathrm{mg}$.m (low hydrophobic character) $[41,42]$.

Table 1. Characteristics of the peat water sample.

\begin{tabular}{|c|c|c|c|c|c|c|c|c|}
\hline \multirow{2}{*}{ No } & \multirow{2}{*}{ Parameter } & \multirow{2}{*}{ Units } & \multicolumn{4}{|c|}{ Week } & \multirow{2}{*}{ Average } & \multirow{2}{*}{ STDEV } \\
\hline & & & $\mathbf{I}$ & II & III & IV & & \\
\hline 1 & $\mathrm{pH}$ & & 6.3 & 6.3 & 6.3 & 6.3 & 6.3 & 0 \\
\hline 2 & $\begin{array}{l}\text { DOC (dissolved } \\
\text { organic carbon) }\end{array}$ & $\mathrm{mg} / \mathrm{L}$ & 36.40 & - & - & 36.40 & 36.4 & - \\
\hline 3 & $\mathrm{UV}_{254}$ absorbance & $1 / \mathrm{cm}$ & 0.968 & 1.005 & 0.977 & 0.955 & 0.976 & 0.02 \\
\hline 4 & $\begin{array}{c}\mathrm{KMnO}_{4} \text { organic } \\
\text { substances }\end{array}$ & $\underset{\mathrm{KMnO}_{4} / \mathrm{L}}{\mathrm{mg}}$ & 120.08 & 126.4 & 120.08 & 113.76 & 120.08 & 5.16 \\
\hline 5 & SUVA $_{254}$ & L/mg.m & 2.659 & 2.761 & 2.684 & 2.624 & 2.682 & 0.006 \\
\hline
\end{tabular}

\subsection{Characterisation of UF-PSf Membranes}

The surface and cross-section SEM images of the prepared membrane are shown in Figure 2. The UF PSf membrane had a tight pore arrangement and sponge-like cross-section morphology without macrovoids (large cavities), which was similar to the membrane structure reported earlier [35]. Based on image-J surface SEM image processing (Figure 3), the surface pore size of the membrane was $0.061 \mu \mathrm{m}$, falling under UF range of $0.001-$ $0.1 \mu \mathrm{m}[44]$.

The polysulfone membrane used in this study had a pore size of less than $0.1 \mu \mathrm{m}$ (Figure 3). However, from the SEM image it is not possible to determine exactly what the pore size is. However, the pore size distribution can determine by utilized Image-J software following the previous research used digital SEM image data. The result of processing SEM images by Image-J can be seen in Figure 3B,C. The results show the average pore diameter of the membrane is $0.061 \mu \mathrm{m}$. Based on literature, the polysulfone membrane used in this work can be categorized as well as ultrafiltration membrane. 

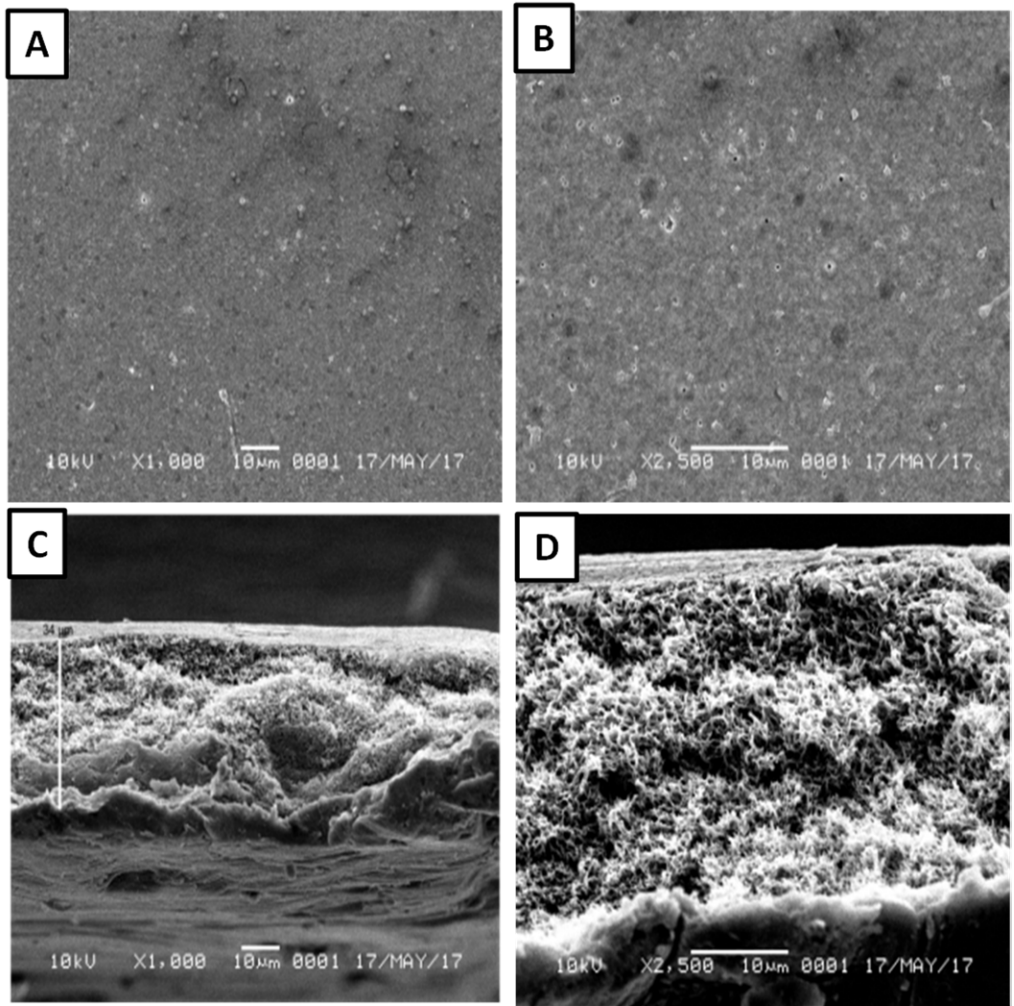

Figure 2. Ultrafiltration polysulfone membrane surface microstructure with (A) magnification of $1000 \times$ and $($ B) magnification $2500 \times$, and cross-section microstructure with $($ C) magnification of $1000 \times$ and (D) magnification $2500 \times$.

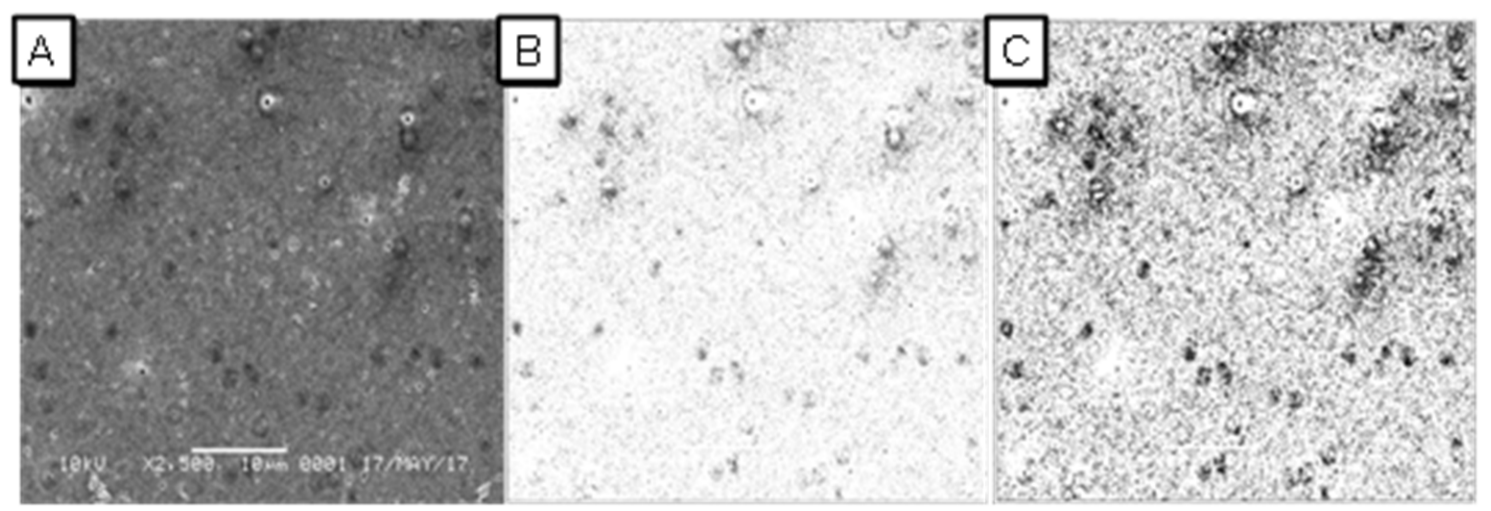

Figure 3. Membrane surface SEM image $(2500 \times)$ processed with Image-J for pore size determination (A) before editing, (B) after threshold and (C) outline image result.

\subsection{Coagulation-Flocculation}

Figure 4 shows that for aluminum sulfate dosings of $125-250 \mathrm{mg} / \mathrm{L}$, the removal efficiency of NOM increased from $125 \mathrm{mg} / \mathrm{L}$ to $175 \mathrm{mg} / \mathrm{L}$ and then a slight decrease until $250 \mathrm{mg} / \mathrm{L}$. Beyond that value, the NOM removal efficiency decreased. The loading restabilization can explain the pattern on the NOM removals as a function of the dosing rate on the addition of $\mathrm{Al}_{2}\left(\mathrm{SO}_{4}\right)_{3}$ coagulant [37]. 


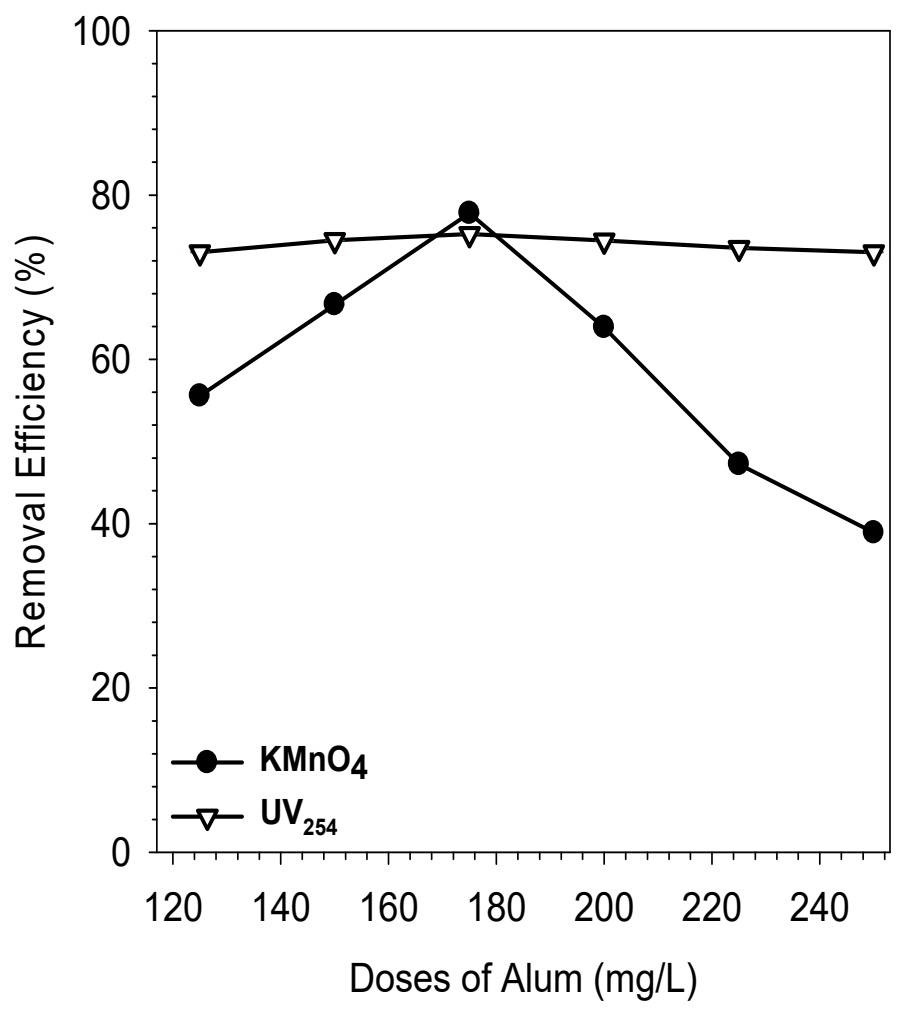

Figure 4. $\mathrm{NOM}$ removal rate represented by oxidation with $\mathrm{KmnO}_{4}$ and $\mathrm{UV}_{254}$ absorbances as a function of doses of alum in the coagulation-flocculation test.

The oxidation of organic substances by $\mathrm{KMnO}_{4}$ peaked at the optimum dose of $175 \mathrm{mg} / \mathrm{L}$. Meanwhile, a slight decrease in $\mathrm{UV}_{254}$ removals was observed. In the process of coagulation-flocculation, the dominant fraction of removed NOM is the one that hydrophobic or with large MWs as detailed elsewhere [31,45]. In addition, according to Suslova et al. [46] that $\mathrm{KmnO}_{4}$ can oxidize various types of organic components irrespective of the MWs.

The NOM removal in the coagulation-flocculation process was achieved optimum at a dose of $175 \mathrm{mg} / \mathrm{L}$ corresponding to organic substances $\mathrm{KmnO}_{4}$ and $\mathrm{UV}_{254}$ absorbance of $77.78 \%$ and $75.24 \%$, respectively. The removal of NOM obtained in this study was higher than the previous studies $[47,48]$. After adding the coagulant, the coagulation rate decreased, as well as the $\mathrm{pH}$ value from 6 to 3.65. It was caused by the reaction of aluminum sulfate with water that produces $\mathrm{H}^{+}$ions. The acidification of water lowered the coagulation/flocculation efficiencies.

\subsection{Coagulation-Adsorption}

The PAC adsorption was carried out after the coagulation/flocculation of the raw peat water sample. Figure 5 shows the rate of NOM removal in the PAC adsorption process. The NOM removal rate was higher than the standalone coagulation-flocculation or adsorption processes reported earlier [32,49]. Increased NOM removal at low $\mathrm{pH}$ during the PAC adsorption can be attributed due to the low $\mathrm{pH}$ of the solution due to the preceding coagulation/flocculation stage [39]. The $\mathrm{pH}$ has a significant effect on activated carbon adsorption and the removal efficiency is higher in acidic than in neutral and alkaline conditions. The presence of $\mathrm{H}^{+}$ions in solution leads to competition between $\mathrm{H}^{+}$ions and NOM bonding [50]. 


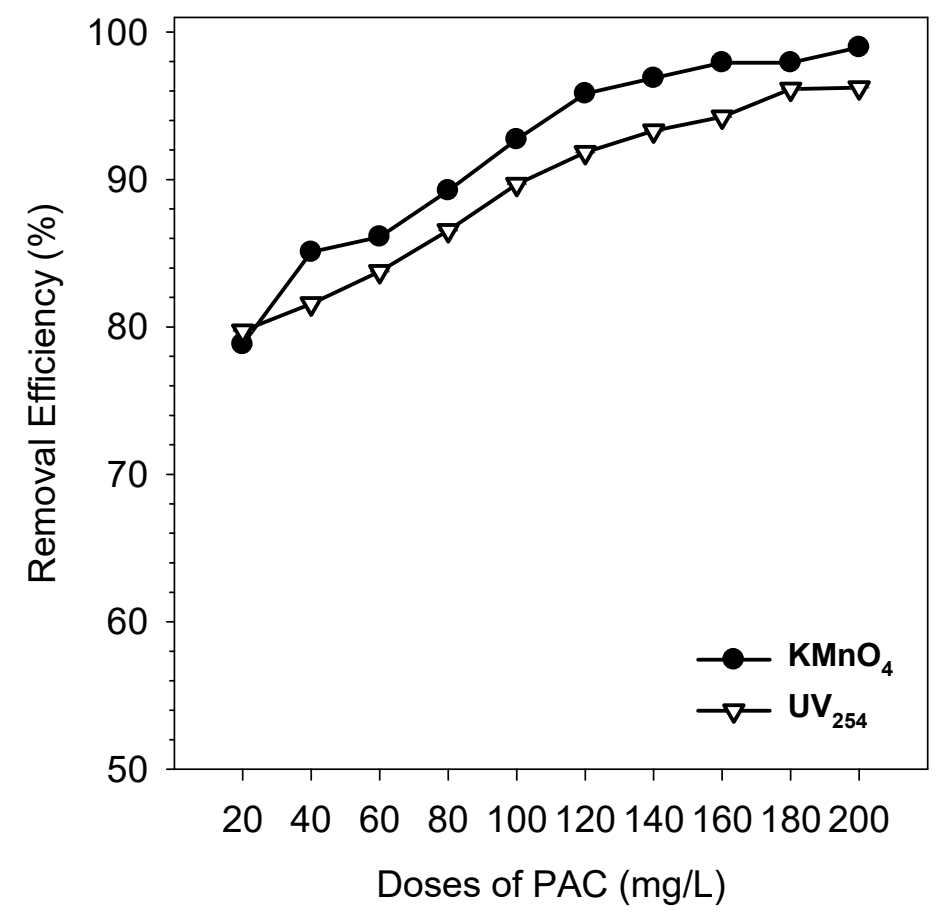

Figure 5. The NOM removal rate represented by organic substances of $\mathrm{KMnO}_{4}$ and $\mathrm{UV}_{254}$ absorbances as function of PAC dosages.

The removal rate of $\mathrm{KmnO}_{4}$-oxidizable organic substances in the coagulation-adsorption process is higher than the $\mathrm{UV}_{254}$ (representing aromatic moieties). The results were the opposite of the coagulation/flocculation process, which could be attributed to the NOM content with large MW removed in the coagulation-flocculation process. As such, only the low MW NOM remained in the PAC adsorption. In previous research, the adsorption process could remove NOM hydrophilic fractions with small MWs [9-11]. The removal rate of $\mathrm{KmnO}_{4}$ organic substances was higher than the $\mathrm{UV}_{254}$ absorbance. These results indicated that $\mathrm{KmnO}_{4}$ organic substances easily oxidized NOM due to their small MWs as stated elsewhere [51].

The best PAC dose was $120 \mathrm{mg} / \mathrm{L}$ of PAC, judging from the highest removal of $\mathrm{KmnO} 4$ and $\mathrm{UV}^{254}$ parameters of $>90 \%$. In addition, the efficiency of NOM removal slightly increased up to $120 \mathrm{mg} / \mathrm{L}$. Due to the NOM removal of 120 to $200 \mathrm{mg} / \mathrm{L}$ being relatively similar, the $120 \mathrm{mg} / \mathrm{L}$ of PAC was chosen because it does not need too much PAC. The removal efficiencies of $\mathrm{KMnO}_{4}$ organic substances and $\mathrm{UV}_{254}$ under the optimum dosing were 95.83 and $91.83 \%$, respectively, as shown in Figure 5. The results obtained in this study were in line with others, e.g., Lee et al. [32] and Aisyahwalsiah [39] using PAC as the adsorbant. Nonetheless, higher NOM removals were obtained in this study. After adding PAC, the $\mathrm{pH}$ increased as reported by others [49] due to the soluble ash, which is rinsed out of the media during use, and the effluent $\mathrm{pH}$ will eventually approach neutral.

\subsection{Coagulation-Adsorption-Membrane Experiments}

The permeability of pure water (aquadest), pretreatment feed, and non-pretreated feed are shown in Figure 6. Based on the results, pure water permeability was obtained of $38-180 \mathrm{~L} / \mathrm{h} . \mathrm{m}^{2}$ by the prepared UF polysulfone membrane. This result exhibits the higher water flux of pure water permeability by low transmembrane pressure compared to commercial polysulfone membrane (Merck) of $150-350 \mathrm{~L} / \mathrm{h} . \mathrm{m}^{2}$ (6-20 bar), which was reported by Adams et al. [52]. 


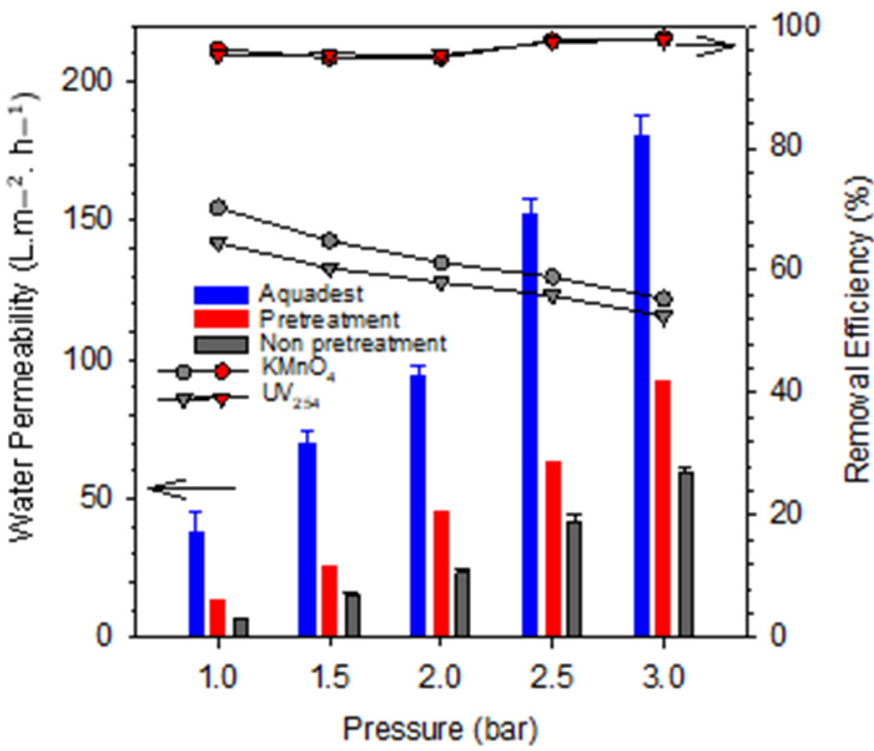

Figure 6. The performance of ultrafiltration of pretreated peat water at different pressures. Aquadest denotes distilled water and represents the permeability of clean water.

Figure 6 shows that the NOM removal efficiency decreased by increasing transmembrane pressure. The results obtained are by previous research, in which the magnitude of NOM rejection is inversely proportional to the applied pressure [53,54]. The deformation of the membrane most probably causes it due to high pressure, which causes membrane compaction that constricts the pore size and the thicker foulant layer that became the secondary filter on top of the PSf membrane.

The NOM removal efficiency reflected from the $\mathrm{KMnO}_{4}$ organic substances was higher than the $\mathrm{UV}_{254}$ absorbance obtained in the adsorption process with PAC. The rejection of NOM by membrane was determined by the adequate pore size [53] and an additional dynamic layer formed on the membrane surface.

In addition to the NOM removal rate, water flux value was also an indicator of the optimum pressure. Figure 6 shows that the water flux value was directly proportional to the pressure. The smallest water flux value was obtained at 1 bar of $13.3 \mathrm{~L} / \mathrm{h} . \mathrm{m}^{2}$, and the highest water flux was at 3 bar of $92.5 \mathrm{~L} / \mathrm{h} . \mathrm{m}^{2}$. The permeability of each pressure to percent removal of $\mathrm{NOM}$ for $\mathrm{KMnO}_{4}$ organic substances and $\mathrm{UV}_{254}$ parameters were determined to determine the optimum pressure. The highest water flux was obtained with the removal rate of $\mathrm{KMnO}_{4}$ and $\mathrm{UV}_{254}$ of 94.79 and $94.66 \%$, respectively. The $\mathrm{UV}_{254}$ rejection of the polysulfone membrane in this work is extremely high over commercial PSf membrane that was only able to remove about $41 \%$ of NOM at 6 bar [52].

The water permeability of treated peat water was smaller than the clean water permeability (Figure 6) due to membrane fouling. However, it was higher by almost two-fold than peat water permeability without pretreatment, which was also similar reported in earlier studies $[31,41,54]$. It was shown that the pretreatment contributed substantially to reducing the membrane fouling [53].

The permeability decrease in the pretreated peat water filtration can be attributed to the fouling by the residual NOM that escaped from the pretreatment. However, previous works by Kang and Choo [41] and Zhang, et al. [55] ascribed the small water permeability to the use of PAC. The bonding of NOM with PAC particles caused the PAC-NOM particles to become an additional foulant that blocks the membrane pores or forms a cake layer on the membrane surface. In this study, the PAC was separated. Hence the foulant was originated from residual NOM in the feed.

Overall findings suggested that the application of coagulation-adsorption pretreatment of UF is promising to reduce the fouling potential on the feed as indicated by in- 
creasing the water permeability value and the removal rate of NOM represented by DOC, $\mathrm{KMnO}_{4}$ organic substance, and absorbance $\mathrm{UV}_{254}$.

In addition, the results obtained were also reinforced with SEM UF-PSF membrane image after treatment. The SEM images in Figure 7 also show the thickness of the UF-PSf membrane (determined from the cross-section SEM image) after being compressed at 3 bars was $85.4 \mu \mathrm{m}$. The pore structure of the membrane after passing the feed water was approximately the same as the pristine membrane. It could be seen on the surface of the membrane there is only a thin layer which is thought to be a cake layer. The additional cake layer helped enhance the rejection of NOM and the final quality of the permeate. It is worth noting that a significant difference in thickness was seen from data in Figures 2C and $7 \mathrm{~B}$. The high variability was originated from the cutting process.
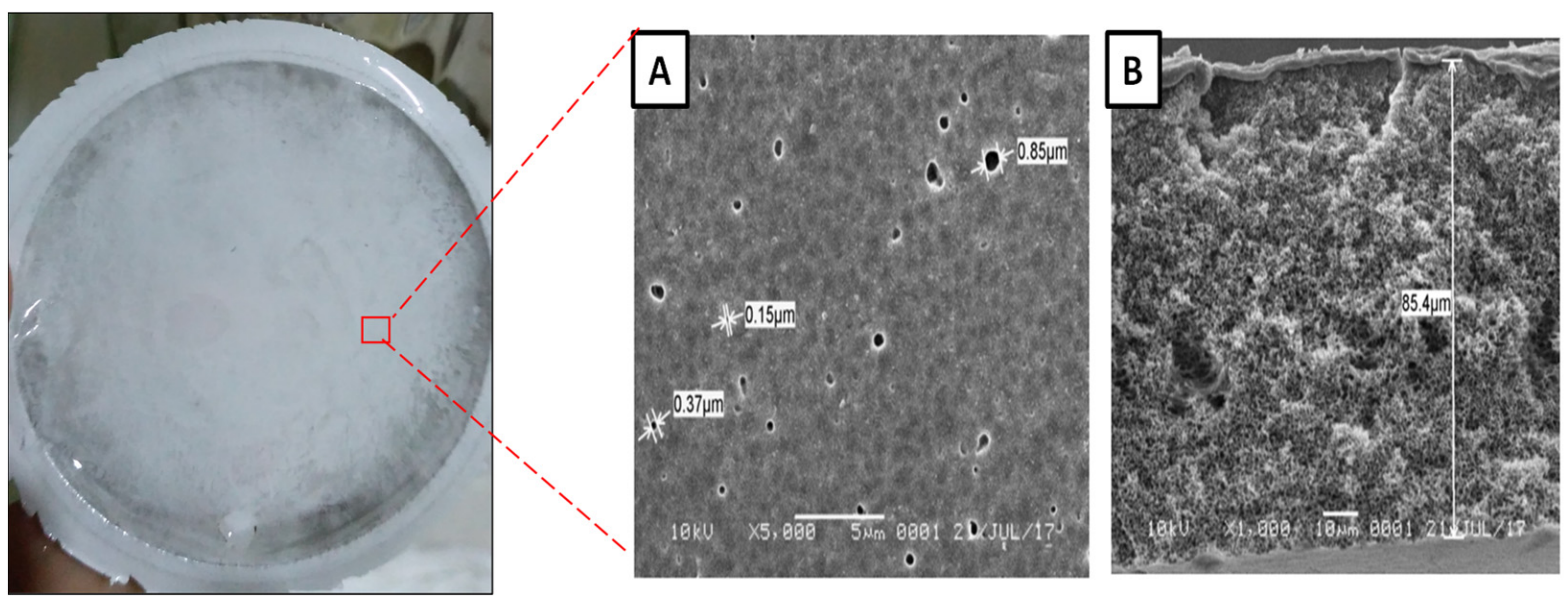

Figure 7. SEM image of used ultrafiltration polysulfone membrane after ultrafiltration process: (A) surface section and (B) cross-sectional.

\section{Conclusions}

This study demonstrated the advantages of combining the coagulation-adsorption process and membrane filtration to treat fouling-prone actual peat water. The coagulationadsorption showed a positive effect as a pretreatment for the ultrafiltration. The pretreated feed showed a lower membrane fouling propensity. The optimum coagulation/flocculation and adsorption condition was at $\mathrm{Al}_{2}\left(\mathrm{SO}_{4}\right)_{3}$ dosing of $175 \mathrm{mg} / \mathrm{L}$ and $\mathrm{PAC}$ dosing of $120 \mathrm{mg} / \mathrm{L}$, respectively. Higher filtration pressure enhanced the peat water permeability. The optimum pressure on the hybrid process was 3 bar with a permeability value of $92.5 \mathrm{~L} / \mathrm{m}^{2} . \mathrm{h}$ and an organic removal rate of $95 \%$. The findings highlight the importance of the hybrid system for treating challenging feeds that otherwise proven difficult when applying a standalone system. Moreover, long-term studies are still required to accurately gauge the performance of the hybrid system for treatment of peat water.

Author Contributions: Conceptualization, M.E. and M.M.; methodology, A.E.P.; software, A.E.P.; validation, A.E.P., M.E. and M.M.; formal analysis, A.R.; investigation, A.E.P.; resources, E.L.A.R.; data curation, A.E.P.; writing-original draft preparation, A.E.P.; writing-review and editing, M.E.; visualization, A.E.P.; supervision, M.M., C.A., M.E. and M.R.B.; project administration, A.E.P., R.R., D.H.Y.Y.; funding acquisition, M.E. All authors have read and agreed to the published version of the manuscript.

Funding: This research received no external funding.

Acknowledgments: The authors thank the Engineering Faculty and Materials and Membranes Research Group ( $\left.\mathrm{M}^{2} \mathrm{ReG}\right)$, Lambung Mangkurat University for the facilities. Muthia thanks the Applied Research of Universities Grant 2021-2023, Basic Research Grant 2021-2022, and World Class Research Grant 2021-2023 Directorate General of Higher Education, Ministry of Education, Culture, Research, and Technology, Republic of Indonesia. 
Conflicts of Interest: The authors declare no conflict of interest.

\section{References}

1. Tang, C.; He, Z.; Zhao, F.; Liang, X.; Li, Z. Effects of Cations on The Formation of Ultrafiltration Membrane Fouling Layers When filtering Fulvic Acid. Desalination 2014, 352, 174-180. [CrossRef]

2. Matilainen, A.; Vepsäläinen, M.; Sillanpää, M. Natural organic matter removal by coagulation during drinking water treatment: A review. Adv. Colloid Interface Sci. 2010, 159, 189-197. [CrossRef] [PubMed]

3. Menya, E.; Olupot, P.; Storz, H.; Lubwama, M.; Kiros, Y. Production and performance of activated carbon from rice husks for removal of natural organic matter from water: A review. Chem. Eng. Res. Des. 2018, 129, 271-296. [CrossRef]

4. McMeen, C.R.; Benjamin, M.M. NOM removal by slow sand filtration through iron oxide-coated olivine. J. Am. Water Work. Assoc. 1997, 89, 57-71. [CrossRef]

5. Zhao, Y.X.; Phuntsho, S.; Gao, B.Y.; Yang, Y.Z.; Kim, J.-H.; Shon, H.K. Comparison of A Novel Polytitanium Chloride Coagulant With Polyaluminium Chloride: Coagulation Performance And Floc Characteristics. J. Environ. Manag. 2015, 147, 194-202. [CrossRef] [PubMed]

6. $\quad$ Dong, B.-Z.; Chen, Y.; Gao, N.-Y.; Fan, J.-C. Effect of Coagulation Pretreatment on The Fouling of Ultrafiltration Membrane. J. Environ. Sci. 2007, 19, 278-283. [CrossRef]

7. Rahma, A.; Elma, M.; Mahmud, M.; Irawan, C.; Pratiwi, A.E.; Rampun, E.L.A. Removal of natural organic matter for wetland saline water desalination by coagulation-pervaporation. J. Kim. Sains Dan Apl. 2019, 22, 85-92. [CrossRef]

8. Elma, M.; Rahma, A.; Pratiwi, A.E.; Rampun, E.L.A. Coagulation as pretreatment for membrane-based wetland saline water desalination. Asia Pac. J. Chem. Eng. 2020, 15, e2461. [CrossRef]

9. Cui, X.; Choo, K.-H. Reviewer Paper: Natural Organic Matter Removal and Fouling Control in Low-Pressure Membrane Filtration for Water Treatment. Environ. Eng. 2014, 19, 1-8.

10. Song, Y.; Dong, B.; Gao, N.; Ma, X. Powder Activated Carbon Pretreatment of A Microfiltration Membrane for The Treatment of Surface Water. Environ. Res. Public Health 2015, 12, 11269-11277. [CrossRef]

11. Liu, S.; Lim, M.; Amal, R. $\mathrm{TiO}_{2}$-Coated Natural Zeolite: Rapid Humic Acid Adsorption And Effective Photocatalytic Regeneration. Chem. Eng. Technol. 2014, 105, 46-52. [CrossRef]

12. Gamage, S.M.K.; Sathasivan, A. A Review: Potential And Challenges of Biologically Activated Carbon to Remove Natural Organic Matter in Drinking Water Purification Process. Chemosphere 2017, 167, 120-138. [CrossRef] [PubMed]

13. Rahma, A.; Elma, M.; Rampun, E.L.A.; Pratiwi, A.E.; Rakhman, A.; Fitriani. Rapid Thermal Processing and Long Term Stability of Interlayer-free Silica-P123 Membranes for Wetland Saline Water Desalination. Adv. Res. Fluid Mech. Therm. Sci. 2020, 71, 1-9. [CrossRef]

14. Rahma, A.; Elma, M.; Pratiwi, A.E.; Rampun, E.L. Performance of interlayer-free pectin template silica membranes for brackish water desalination. Membr. Technol. 2020, 2020, 7-11. [CrossRef]

15. Lestari, R.A.; Elma, M.; Rahma, A.; Suparsih, D.; Anadhliyah, S.; Sari, N.L.; Pratomo, D.A.; Sumardi, A.; Lestari, A.E.; Assyaifi, Z.L.; et al. Organo Silica Membranes for Wetland Saline Water Desalination: Effect of membranes calcination temperatures. E3S Web Conf. 2020, 148, 07006. [CrossRef]

16. Elma, M.; Rampun, E.L.A.; Rahma, A.; Assyaifi, Z.L.; Sumardi, A.; Lestari, A.E.; Saputro, G.S.; Bilad, M.R.; Darmawan, A. Carbon templated strategies of mesoporous silica applied for water desalination: A review. J. Water Process Eng. 2020, $38,101520$. [CrossRef]

17. Elma, M.; Mujiyanti, D.R.; Ismail, N.M.; Bilad, M.R.; Rahma, A.; Rahman, S.K.; Rakhman, A.; Rampun, E.L.A. Development of Hybrid and Templated Silica-P123 Membranes for Brackish Water Desalination. Polymers 2020, 12, 2644. [CrossRef]

18. Elma, M.; Riskawati, N.; Marhamah. Silica Membranes for Wetland Saline Water Desalination: Performance and Long Term Stability. IOP Conf. Ser. Earth Environ. Sci. 2018, 175, 012006. [CrossRef]

19. Elma, M.; Hairullah; Assyaifi, Z.L. Desalination Process via Pervaporation of Wetland Saline Water. IOP Conf. Ser. Earth Environ. Sci. 2018, 175, 012009. [CrossRef]

20. Elma, M.; Setyawan, H.; Rahma, A.; Pratiwi, A.; Rampun, E.L.A. Fabrication of Interlayer-free P123 Caronised Template Silica Membranes for Water Desalination: Conventional Versus Rapid Thermal Processing (CTP vs RTP) Techniques. IOP Conf. Ser. Mater. Sci. Eng. 2019, 543, 012076. [CrossRef]

21. Elma, M.; Setyawan, H. Synthesis of Silica Xerogels Obtained in Organic Catalyst via Sol Gel Route. IOP Conf. Ser. Earth Environ. Sci. 2018, 175, 012008. [CrossRef]

22. Rahman, S.K.; Maimunawaro; Rahma, A.; Syauqiah, I.; Elma, M. Functionalization of hybrid organosilica based membranes for water desalination-Preparation using Ethyl Silicate 40 and P123. Mater. Today: Proc. 2020, 31, 60-64. [CrossRef]

23. Mawaddah, Y.; Wati, L.S.; Rampun, E.L.A.; Sumardi, A.; Lestari, A.E.; Elma, M. FTIR Studies of the TEOS/TEVS xerogel structure using rapid thermal processing method. Konversi 2020, 9, 73-78. [CrossRef]

24. Maimunawaro; Rahman, S.K.; Rampun, E.L.A.; Rahma, A.; Elma, M. Deconvolution of carbon silica templated thin film using ES40 and P123 via rapid thermal processing method. Mater. Today Proc. 2020. [CrossRef] 
25. Lestari, A.E.; Elma, M.; Rabiah, S.; Rampun, E.L.A.; Rahma, A.; Pratiwi, A.E. Performance of Mesoporous Organo Silica Membrane for Desalination. In Proceedings of Materials Science Forum; Trans Tech Publications Ltd.: Bäch, Switzerland, 2020 ; pp. $285-292$.

26. Elma, M.; Rezki, M.R.; Mahmud, M.; Sunardi, S.; Pratiwi, E.N.; Oktaviana, E.N.; Fatimah, S.; Rahma, A. Membran karbon templated silika dari karbon nipah (Nypa fruticans) untuk aplikasi desalinasi air rawa asin [Carbon templated silica membranes from nypa carbon (Nypa fruticans) applied for wetland saline water desalination]. J. Ris. Ind. Has. Hutan 2020, 12, 83-92. [CrossRef]

27. Elma, M.; Pratiwi, A.E.; Rahma, A.; Rampun, E.L.A.; Handayani, N. The Performance of Membranes Interlayer-Free Silica-Pectin Templated for Seawater Desalination via Pervaporation Operated at High Temperature of Feed Solution. Mater. Sci. Forum 2020, 981, 349-355. [CrossRef]

28. Elma, M.; Fitriani; Rakhman, A.; Hidayati, R. Silica P123 Membranes for Desalination of Wetland Saline Water in South Kalimantan. IOP Conf. Ser. Earth Environ. Sci. 2018, 175, 012007. [CrossRef]

29. Mahmud; Elma, M.; Rampun, E.L.A.; Rahma, A.; Pratiwi, A.E.; Abdi, C.; Rosadi, R. Effect of Two Stages Adsorption as PreTreatment of Natural Organic Matter Removal in Ultrafiltration Process for Peat Water Treatment. Mater. Sci. Forum 2020, 988, 114-121. [CrossRef]

30. Herwati, N.; Mahmud; Abdi, C. Pengaruh pH Air Gambut Terhadap Fouling Membran Ultrafiltrasi. Jukung J. Tek. Lingkung 2015, 1,59-73.

31. Mahmud; Abdi, C.; Mu'min, B. Removal Natural Organic Matter (NOM) in Peat Water from Wetland Area by CoagulationUltrafiltration Hybrid Process with Pretreatment Two-Stage Coagulation. J. Wetl. Environ. Manag. 2013, 1, 42-49. [CrossRef]

32. Lee, J.; Vigneswaran, S.; Zhang, Y.; Raj Reddy, R.S.; Liu, Z. Effective Natural Organic Matter Removal In Pond Water by Carbon Nanotube Membrane with Flocculation/Adsorption. Water Sci. Technol. Water Supply 2017, 17, 1080-1087. [CrossRef]

33. Aryanti, P.T.P.; Joscarita, S.R.; Wardani, A.K.; Subagjo; Ariono, D.; Wenten, I.G. The Influence of PEG 400 and Acetone on Polysulfone Membrane Morphology and Fouling Behaviour. J. Eng. Technol. Sci. 2016, 48, 135-149. [CrossRef]

34. Wardani, A.K. Effect of Additives on Polysulfone Based Ultrafiltration Membrane For Peat Water Purification; Institut Teknologi Bandung: Bandung, Indonesia, 2013; pp. 1-37.

35. Tutriyanti. Synthesis and Characterization of Polysulfone Membranes by Phase Inversion Technique: Effect of Concentration of Impregnant $\mathrm{KCl}$ on Coagulant Against Pore Structure of Membranes. Bachelor's Thesis, Universitas Lambung Mangkurat, Banjarbaru, Indonesia, 2017.

36. Ariono, D.; Aryanti, P.T.P.; Subagjo, S.; Wenten, I.G. The Effect of Polymer Concentration on Flux Stability of Polysulfone Membrane. In Proceedings of the International Conference on Engineering Science and Nanotechnology (ICESNANO 2016), Solo, Indonesia, 3-5 August 2016; American Institute of Physics: College Park, MD, USA, 2017; pp. 1-10.

37. Saputra, A.A. Hybrid Coagulation-Ultrafiltration Process in Removing Natural Organic Matter (NOM) in Peat Water: The Effect of Variations in Coagulant Doses on Membrane Fouling. Bachelor's Thesis, Universitas Lambung Mangkurat, Banjarbaru, Indonesia, 2014.

38. Kurniawan, C.; Waluyo, T.B.; Sebayang, P. Particle Size Analysis Using Free Software Image-J. In Seminar Nasional Fisika; Pusat Penelitian Fisika-LIPI: Jakarta, Indonesia, 2011; pp. 1-8.

39. Aisyahwalsiah, A. Optimization of Peat Water Treatment Using a Combined Process of Coagulation with Peaty Clay and Activated Carbon Adsorption. Bachelor's Thesis, Universitas Lambung Mangkurat, Banjarbaru, Indonesia, 2013.

40. Mahmud; Notodarmojo, S.; Padmi, T.; Soewondo, P. Adsorpsi Bahan Organik Alami (BOA) Air Gambut Pada Tanah Lempung Gambut Alami dan Teraktivasi: Studi Kesetimbangan Isoterm dan Kinetika Adsorpsi. INFO-TEKNIK 2012, $13,28-37$.

41. Kang, S.K.; Choo, K.H. Why Does A Mineral Oxide Adsorbent Control Fouling Better than Powdered Activated Carbon in Hybrid Ultrafiltration Powder Treatment? J. Membr. Sci. 2010, 355, 69-77. [CrossRef]

42. Jeong, K.; Kim, D.G.; Ko, S.O. Adsorption Characteristics of Effluent Organic Matter and Natural Organic Matter by Carbon Based Nanomaterials. KSCE J. Civ. Eng. 2016, 21, 119-126. [CrossRef]

43. Zularisam, A.W.; Ismail, A.F.; Salim, M.R.; Sakinah, M.; Matsuura, T. Application of Coagulation-Ultrafiltration Hybrid Process for Drinking Water Treatment: Optimization of Operating Conditions Using Experimental Design. Sep. Purification Technol. 2009, 65, 193-210. [CrossRef]

44. Mulder, M. Basic Principles of Membrane Technology; Kluwer Academic Publishers: Dordrecht, The Netherland, 1996.

45. Chih, Y.C.; Chung, Y.W.; Ying, C.C. The Coagulation Characteristics of Humic Acid By Using Acid-Soluble Chitosan, Water-Soluble Chitosan, And Chitosan Coagulant Mixtures. Environ. Technol. 2014, 36, 1141-1146.

46. Suslova, O.; Govorukha, V.; Brovarskaya, O.; Matveeva, N.; Tashyreva, H.; Tashyrev, O. Method for Determining Organic Compound Concentration in Biological Systems by Permanganate Redox Titration. Int. J. Bioautomation 2014, 18, 45-52.

47. Rahman, R.A. Hybrid Coagulation-Ultrafiltration Process in Removal Natural Organic Matter (NOM) in Peat Water: Effect of Coagulants Type and Stirring Speed on Membrane Fouling. Bachelor's Thesis, Universitas Lambung Mangkurat, Banjarbaru, Indonesia, 2014.

48. Fachrozi, M. Ultrafiltration Coagulation Hybrid Process in Removal Natural Organic Matter (NOM) in Peat Water: Effect of Coagulants Type on Membrane Fouling. Bachelor's Thesis, Universitas Lambung Mangkurat, Banjarbaru, Indonesia, 2013.

49. Tomaszewska, M.; Mozia, S.Y.; Morawski, A.W. Removal of Organic Matter by Coagulation Enhanced with Adsorption on PAC. Desalination 2004, 161, 79-87. [CrossRef] 
50. Abdillah, A.I.; Darjito; Khunur, M.M. Pengaruh pH dan Waktu Kontak pada Adsorpsi Ion Logam Cd ${ }^{2+}$ Menggunakan Adsorben Kitin Terikat Silang Glutaraldehid. Kim. Stud. J. 2015, 1, 826-832.

51. Oxidation of Organic Molecules by $\mathrm{KMnO}_{4}$; National Science Foundation University of California, LibreTexts Library: Sacramento, CA, USA, 2015.

52. Adams, F.V.; Nxumalo, E.N.; Krause, R.W.M.; Hoek, E.M.V.; Mamba, B.B. Application of polysulfone/cyclodextrin mixed-matrix membranes in the removal of natural organic matter from water. Phys. Chem. Earth Parts A/B/C 2014, 67-69, 71-78. [CrossRef]

53. Notodarmojo, S.; Deniva, A. Penurunan Zat Organik dan Kekeruhan Menggunakan Teknologi Membran Ultrafiltrasi dengan Sistem Aliran Dead-End (Studi Kasus: Waduk Saguling, Padalarang). Proc. ITB Sains Technol. A 2004, 36, 63-82. [CrossRef]

54. Aryanti, P.T.P.; Khoiruddin; Wenten, I.G. Influence of Additives on Polysulfone-Based Ultrafiltration Membrane Performance during Peat Water Filtration. J. Water Sustain. 2013, 3, 85-96. [CrossRef]

55. Zhang, M.; Li, C.; Benjamin, M.M.; Chang, Y. Fouling and Natural Organic Matter Removal in Adsorbent/Membrane Systems for Drinking Water Treatment. Environ. Sci. Technol. 2003, 37, 1663-1669. [CrossRef] [PubMed] 